\title{
Editorial: Arctic marine biodiversity under change
}

\author{
Haakon Hop • Tore Haug • Stig Falk-Petersen
}

Received: 14 July 2011 / Accepted: 1 August 2011 /Published online: 11 August 2011

(C) Senckenberg, Gesellschaft für Naturforschung and Springer 2011

Marine biodiversity in the Arctic is changing in response to altered physical environment, subsequent and ecological changes as well as anthropogenic disturbances (Wassmann et al. 2011). The Arctic region has become warmer in the past three decades (ACIA 2005), and most global climate models indicate a continued, likely accelerated, warming trend in the coming decades (IPCC 2007). Assessing consequences of climatic change to Arctic marine ecosystems is contingent upon identifying the physical drivers that regulate biological communities and understanding the mechanisms involved. Changes in the physical marine environment mainly involve oceanographic- (temperature, salinity and $\mathrm{pH}$ ) and ice conditions, whereas ecological changes typically include altered species distributions, community structure as well as species invasions. Additional perturbations may be caused by anthropogenic effects from fisheries, industrial resource utilization and atmospheric emissions (AMAP 2009). The evidence for footprints of climate change in Arctic marine environments is accumulating, but the research efforts evaluating the impacts of climate change on Arctic marine biodiversity are still rather limited (Wassmann et al. 2011).

Marine biodiversity is intimately linked to ecosystem function. In order to assess changes in Arctic marine biodiversity, we need to know how the ecological communities and their species are structured and how they

H. Hop $(\bowtie) \cdot$ S. Falk-Petersen

Norwegian Polar Institute, Fram Centre,

9296 Tromsø, Norway

e-mail: Haakon.Hop@npolar.no

T. Haug

Institute of Marine Research,

Box 6404, 9294 Tromsø, Norway function, within a first-order descriptive framework. For the Arctic marine environment, this knowledge is still fragmented, and few long-term data series exist. Arctic ecosystems are understudied due to logistic challenges and high research costs. Gaps in research on marine biodiversity need to be filled soon in order to describe and understand the magnitude and extent of changes observed. Ongoing changes in the Arctic marine environment have put the ecosystems of Arctic seas, and the organisms living within them, on the agenda of research institutions, managers and governments.

Marine Biodiversity has recently gotten an increased focus through the International Census for Marine Life (CoML), launched in 2000 (Yarincik and O'Dor 2005). The Arctic Ocean Diversity project (ArcOD), an Arctic component of CoML, was launched in 2004 (Gradinger et al. 2010). The ArcOD has involved a rather large effort (> 100 scientists) to compile existing data, taxonomically identify samples still in boxes or on shelves, and collect new samples to fill regional gaps. These projects, and the wide dissemination of their results (e.g., www.arcodiv.org), have caused a rejuvenated interest in marine biodiversity.

Consequently, "Marine Biodiversity under change" was a topic on the international Arctic Frontiers Conference 2010 in Tromsø, Norway. Pan-Arctic presentations on Arctic Marine Biodiversity are presented in a prior volume of Marine Biodiversity (Bluhm et al. 2011). The 9 papers in this volume include more specific, and regionally focused, research and include a range of topics such as marine biodiversity, life history and invasions. The papers in this volume can be grouped as follows: pelagic diversity (2), fishes (2), benthos (4) and invasive species (1). These results fill important gaps in our knowledge by targeting little studied research topics or species, or times of the year when little prior research has been conducted. Some studies combine data from historical surveys with current inves- 
tigations to assess changes in biological communities, and one study specifically deals with observed changes in the environment due to invasion of exotic species.

\section{Pelagic diversity}

Sediment traps provide a method to sample mobile pelagic organisms over a season or throughout the year. Using traps deployed in the eastern part of Fram Strait at 200-300 m depth for several years, Kraft et al. (2011) documented the dominant role of amphipods of the genus Themisto in this region. Observed shifts in the dominance of the Arctic Themisto libellula to the Atlantic species T. abyssorum and T. compressa, from 2000-2007, indicated a biological response to the temperature increase in the northward flowing Atlantic water.

Many pelagic organisms undertake diel vertical migration (DVM), even during midnight sun in the Arctic during summer-autumn. Hydroacoustics coupled with depthstratified plankton sampling north and north-west of Svalbard showed diurnal differences in density (backscatter) and abundance of mesozooplankton, involving mainly Calanus finmarchicus and C. glacialis in the upper $50 \mathrm{~m}$ and Metridia longa deeper in the water column (Rabindranath et al. 2011). In addition to the mesozooplankton DVM signal, pronounced day/night differences in macrozooplankton vertical distribution were found at the fjord stations in particular. Since many of the larger zooplankton and nekton are predators, their presence may influence mesozooplankton behaviour though predator avoidance. The DVM signal in the species studied was also linked to the highly variable Arctic plankton bloom, which mesozooplankton depend on for an abundant food source.

\section{Fishes}

Some fish species in the Arctic are poorly known with regard to their ecology and life history. Meyer Ottesen et al. (2011) contributed substantially to the knowledge of the daubed shanny (Leptoclinus maculatus Family Stichaeidae), an abundant fish in Arctic waters. They found that postlarvae, which remain in the pelagic environment for 23 years before settling to the bottom, have a unique lipid sac that enables them to store large energy reserves that they can utilize when food becomes scarce during winter. This lipid sac is likely an adaptation for survival in high-Arctic waters, since it is not found in postlarvae from more southern areas.

Jan Mayen is an isolated island in the North Atlantic on the borderline to the Arctic. The marine biodiversity around this island is poorly known, in spite of marine investigations conducted at irregular intervals since 1877 . However, more recent surveys have provided a substantial data base for marine fishes in this area. Wienerroither et al. (2011) provide an annotated list of 71 fish species recorded in the Fisheries Zone around Jan Mayen and give an overview of the changes in species composition and distribution from 1877 to 2009. A pronounced increase in the number of species over the last 40 years, with 40 of the 71 species recorded after 1971, indicates increased research effort as well as increased species' distribution ranges. The data provide important baseline information for future monitoring of this area.

\section{Benthic studies}

Marine biodiversity in Arctic subtidal hard-bottom areas is poorly known, since the sampling typically involves logistic-intensive SCUBA diving. Chenelot et al. (2011) sampled at 50 sites (2006-2007) from the Eastern to Western Aleutians Islands, Alaska, as part of the Alaska Monitoring and Assessment Program. Abundant, thick crustose coralline algae (Clathromorphum nereostratum) found at these sites provided microhabitats for 707 invertebrate taxa, many of which were cryptic within the $2-10 \mathrm{~cm}$ thick matrix of corallines. The crustose environment supported faunal communities as diverse and abundant as those found in rich macroalgal habitats.

Most research efforts in the Arctic have been carried out during the summer, and relatively little is known about the survival of biological communities during winter. The nearshore, benthic fauna at 5-35 m depth in Kongsfjorden, Svalbard, comprised 120 taxa during winter, with abundance and biomass reaching up to 11,800 ind. $\mathrm{m}^{-2}$ and $180 \mathrm{gm}^{-2}$ at $15 \mathrm{~m}$ depth (Kedra et al. 2011). Even though 26 more taxa were found during the summer, the shallow-water benthic fauna remained relatively stable throughout the year and comprised mainly deposit feeders. Carnivorous and opportunistic species increased in abundance during the winter.

Benthic biodiversity in the Russian Arctic has been studied for many years, which makes it possibly to detect changes over time. Solyanko et al. (2011) compared sublittoral macrobenthic fauna of the Gorlo Strait, White Sea, in 2004 with surveys in 1992 and 1980's. The benthic macrofauna was quite rich with a total of 322 species identified from all surveys, representing 254 genera and 166 families. The authors attributed the high rate of rare species to high spatialtemporal variation, mainly with regard to fragmented and unstable habitats as well as variable, overall low food supply. Although the study revealed a few North Atlantic species not so far recorded in the White Sea, the minor changes observed over time in taxonomic distinctness indices and community composition indicated stability. Thus, climate change has probably not yet affected specific oceanographic conditions 
and benthic habitats of the Gorlo, which shape the local macrobenthic fauna.

Nematodes comprise a diverse group of organisms in soft-bottom habitats. A study by Sharma and Bluhm (2011) from the Arctic marginal and deep-sea (640$3848 \mathrm{~m}$ depth), north of Alaska and Canada, found a total of 84 genera of nematodes from 25 families. Abundances ranged up to 6800 ind. $\mathrm{m}^{-2}$ and were considerably higher in the Chukchi Sea and in the Amundsen Gulf than in the Canada Basin abyss. A dominance of large detritivores and deposit-feeding nematodes suggested that they play an important role in carbon recycling in the benthic deep-sea food web.

\section{Invasive species}

Marine biodiversity in the Arctic is affected by invasive or introduced species. One such example is the red king crab (Paralithodes camtschaticus), which was introduced from the northern Pacific to the Russian Murman coast during the 1960s and the 1970s. Over the last decades, the crab has become established in northern Norway waters, where it continues to spread westward. This crab species is an active predator on benthic fauna, especially feeding in deep softbottom sediments. In the Varanger area of northern Norway, close to the Russian border, Oug et al. (2011) found that the soft-bottom epifauna and infauna had become markedly reduced in crab invaded areas, when comparing the fauna in 2007-2009 with that in 1994 before the rapid increase in crab abundance. Since the crab selectively removes echinoderms, non-moving burrowing and tube-dwelling polychaetes as well as large-sized bivalves, the functional diversity at their feeding sites had become reduced, relative to the earlier situation. Also, the soft-bottom habitat had become degraded due to hypoxic conditions with low bioturbation of sub-surface layers, which suggested that the crabs had removed organisms performing important functions such as irrigation and sediment reworking. Such changes may have implications for ecosystem production and response to other stress factors.

The articles in this volume provide much needed knowledge on biodiversity in different marine environments of the Arctic. Remaining knowledge gaps and challenges are pointed out and the data presented herein can be built on in future research projects in still uncharted Arctic waters.
Acknowledgements The majority of these papers were originally presented at the Arctic Frontiers conferences in Tromsø, January 2010. The support and initiative of ARCTOS (www.arctosresearch.net) and Arctic Frontiers (www.arctic-frontiers.com) are gratefully acknowledged.

\section{References}

ACIA (2005) Impacts of a warming Arctic: Arctic climate impact and assessment. Cambridge University Press, Cambridge

AMAP (2009) Update on selected climate issues of concern. Arctic Monitoring and Assessment Programme, Oslo

Bluhm BA, Gradinger R, Hopcroft RR (2011) Arctic ocean diversity: synthesis. Mar Biodiv 41:1-4

Chenelot H, Jewett SC, Hoberg MK (2011) Macrobenthos of the nearshore Aleutian Archipelago, with emphasis on invertebrates associated with Clathromorphum nereostratum (Rhodophyta, Corralinaceae). Mar Biodiv, this issue

Gradinger R, Bluhm BA, Hopcroft RR, Gebruk A, Kosobokova K, Sirenko B, Weslawski JM (2010) Chapter 10. Marine life in the Arctic. In: MacIntyre A (ed) Life in the world's ocean: diversity, distribution, abundance. Wiley-Blackwell pp 183-202

IPCC (2007) Climate Change 2007: The physical science basis. Working Group I, Contribution to the Fourth Assessment Report of the IPCC Intergovernmental Panel on Climate Change. University Press, Cambridge

Kedra M, Legezynska J, Walkusz W (2011) Shallow winter and summer macrofauna in high Arctic fjord ( $79^{\circ} \mathrm{N}$, Spitsbergen). Mar Biodiv, this issue

Kraft A, Bauerfind E, Nöthig, E-M (2011) Amphipod abundance in sediment trap samples at the long-term observatory HAUSGARTEN (Fram Strait, $\sim 79^{\circ} \mathrm{N} / 4^{\circ} \mathrm{E}$ ). Variability in species community patterns. Mar Biodiv, this issue

Meyer Ottesen CA, Hop H, Christiansen JS, Falk-Petersen S (2011) Early life history of daubed shanny (Teleostei: Leptoclinus maculatus) in Svalbard waters. Mar Biodiv, this issue

Oug E, Cochrane SKJ, Sundet JH, Norling K, Nilsson HC (2011) Effects of the invasive king crab (Paralithodes camtschaticus) on soft-bottom fauna in Varangerfjorden, northern Norway. Mar Biodiv, this issue

Rabindranath A, Daase M, Falk-Petersen S, Wold A, Wallace MI, Berge J, Brierly AS (2011) Seasonal and diel vertical migration of zooplankton in the High Arctic during the autumn midnight sun of 2008. Mar Biodiv, this issue

Sharma J, Bluhm BA (2011) Diversity of larger free-living nematodes from macrobenthos $(>250 \mu \mathrm{m})$ in the Arctic deep-sea Canada Basin. Mar Biodiv, this issue

Solyanko K, Spiridonov V, Naumov A (2011) Benthic fauna of the Gorlo Strait, White Sea: a first species inventory based on data from three different decades from the 1920s to 2000s. Mar Biodiv, this issue

Wassmann P, Duarte CM, Agusti S, Sejr MK (2011) Footprints of climate change in the Arctic marine ecosystem. Glob Change Biol 17:1235-1249

Wienerroither RM, Nedreaas KH, Uiblein F, Christiansen JS, Byrkjedal I, Karamoushko O (2011) The marine fishes of Jan Mayen Island, NE Atlantic - past and present. Mar Biodiv, this issue

Yarincik K, O’Dor R (2005) The census of marine life: goals, scope and strategy. Sci Mar 69:201-208 